\title{
ALTERNATIF PENYELESAIAN KEKERASAN TERHADAP PEREMPUAN
}

\author{
Maria Silvya E. Wangga \\ R. Bondan Agung Kardono \\ Mahasiswa Program Doktor Ilmu Hukum \\ Fakultas Hukum Universitas Diponegoro Semarang
}

\begin{abstract}
ABSTRAK
Kekerasan terhadap perempuan merupakan suatu fenomena sosial yang sangat dekat dan tidak dapat kita sembunyikan lagi dari kehidupan sosial manusia. Pada dasarnya setiap tindakan kekerasan selalu mengakibatkan perusakan terhadap emosi, psikologi, seksual, fisik dan atau material. Undang-Undang Nomor 23 Tahun 2004 tentang Penghapusan Kekerasan Dalam rumah Tangga, merupakan ketentuan khusus yang memberikan perlindungan terhadap perempuan. Bertitik tolak pada pandangan bahwa masalah kehidupan manusia yang begitu kongkrit, luas dan kompleks dalam masyarakat, tidak hanya harus dipecahkan dengan undang-undang, karena undang-undang bukan satu-satunya sumber hukum, akan tetapi masih ada sumber-sumber lainnya yang dapat digunakan dalam penyelesaian dan penegakkan hukum di masyarakat, yakni forum penyelesaian sengketa berbasis komunitas biasa yang dijumpai dalam kehidupan keseharian. Seperti Shariah Councils, yang berlaku untuk kalangan perempuan muslim Asia Selatan yang tinggal di Inggris atau pengadilan keluarga, (family Court), yang ada di New Zealand. Adanya kajian yang komprehensif serta melakukan studi interdisipliner maka alternatif pengadilan keluarga dalam menyelesaikan perkara kekerasan terhadap perempuan, menjadi suatu paradigma yang dapat diterapkan di indonesia.
\end{abstract}

Kata kunci : Kekerasan terhadap perempuan, Alternatif penyelesaian kekerasan terhadap perempuan

\begin{abstract}
Violence against women is a social phenomenon. Basically, violence always brings about emotional, psychological, sexual, physical, and financial damages. Law Number 23 of 2004 concerning the Elimination of Domestic Violence is a special legal instrument to protect women.As humans' daily problems are so concrete, broad, and complicated, not only are settled by the law, the violence against women should be treated by another approach applicable to settle the issue named a community-based dispute settlement forum, such as Sharia Councils which applies to Asian Muslim women living in England or family courts which are established in New Zealand. The comprehensive studies related to this essential should be a driver to get the notion of this court delivered as well as implemented in Indonesia.
\end{abstract}

Keywords: violence against women, dispute settlement 


\section{PENDAHULUAN}

Kekerasan terhadap perempuan merupakan suatu fenomena sosial yang tidak dapat kita sembunyikan lagi karena menjadi bagian yang tak terpisahkan dari kehidupan sosial manusia. Pada dasarnya setiap tindakan kekerasan selalu mengakibatkan perusakan terhadap emosi, psikologi, seksual, fisik dan atau material $^{1}$. Kekerasan ini dapat dilakukan secara individual dan kelompok ${ }^{2}$. Konflik antara kelompok dapat kita lihat dalam konflik-konflik sosial antara pendukung partai politik, konflik antara warga negara (buruh) dengan aparatur negara (polisi), konflik antara organisasi massa, konflik antara komunitas sosial, konflik antara pelajar dan lain sebagainya. Sedangkan konflik yang dilakukan secara individual adalah kekerasan yang dilakukan oleh seseorang terhadap seseorang lainnya karena berbagai motif seperti perampokan, balas dendam dan lain sebagainya ${ }^{3}$.

Kekerasan yang dialami oleh perempuan dapat terjadi dalam rumah tangga, keluarga maupun di masyarakat, dan kekerasan dalam keluarga pada dasarnya melibatkan setiap komponen dalam keluarga itu sendiri, meliputi suami, isteri dan anak-anak. Sekalipun pada dasarnya relasi antara komponen-komponen itu diafirmasi dan dibangun atas dasar cinta dengan komitmen untuk saling melindungi, namun tidak dapat dihindari kenyataan bahwa kekerasan sering menghantui relasi cinta yang dibangun. Ada banyak faktor yang mendorong terjadinya kekerasan dalam rumah tangga, dapat disinggung di sini seperti faktor ekonomi, cemburu, karakter emosional yang tidak stabil dan hegemoni patriarkhi dalam rumah tangga, yang kondusif mendorong terjadinya kekerasan yang dilakukan oleh satu komponen terhadap komponen yang lainnya ${ }^{4}$. Hal ini disebabkan oleh distribusi kekuasaan, prestise sosial dan hak -hak istimewa antara satu komponen dengan komponen yang lainnya berlangsung tidak seimbang. Dan dalam konteks budaya patriarkhi suami berkuasa dan memiliki hak-hak istimewa terhadap isterinya dan demikianpun relasi orang tua dengan anak-anak.

1 Adam Kuper \& Jessica Kuper, Ensiklopedi Ilmu-Ilmu Sosial, (diterjemahkan oleh Harismunandar, dkk.), Jakarta: PT. Raja Grafindo Persada, 2000, hal.1122

${ }^{2}$ Maria Silvya E. Wangga, Kekerasan Dalam Rumah Tangga dan Usaha Merumuskan Relasi Familial Yang Demokratis, Jurnal Ilmu Hukum Universitas Islam Syekh Yusuf, Tangerang, 2007, hlm.1

${ }^{3}$ ibid

${ }^{4}$ ibid 
Isu kekerasan terhadap perempuan dan kelahiran instrumen hukum untuk menghapuskan kekerasan domestik terhadap perempuan di Indonesia, tidak terlepas dari kontribusi gerakan perempuan dalam upaya memajukan hak perempuan. Sejarah gerakan perempuan masa kini, mengharapkan penegakkan hukum terhadap perempuan mampu memberikan kepastian hukum (Rechtssicherheit), kemanfaatan (zweckmassigkeit) dan keadilan (gerechtigkeit) bagi perempuan, hal ini secara progresif dengan dikeluarkannya Undang-Undang No. 23 Tahun 2004 tentang Penghapusan Kekerasan Dalam Rumah Tangga.

Menurut laporan Komnas Perempuan Tahun 2017 yang telah mengirimkan 674 lembar formulir kepada mitra Komnas Perempuan di seluruh Indonesia dengan tingkat respon pengembalian mencapai 34\%, yaitu 233 formulir. Pada tahun 2016, sebanyak 780 lembar formulir dan tahun 2015 sebanyak 664 formulir. Dalam tahun 2016 jumlah kasus kekerasan terhadap perempuan sebesar 259.150, yang sebagian besar berasal dari kasus yang ditangani oleh Pengadilan Agama. Namun demikian, data ini berasal dari 3 sumber, antara lain ${ }^{5}$ :

a. Pengadilan Agama atau Badan Peradilan Agama (PA-BADILAG) sejumlah 245.548 kasus;

b. Lembaga layanan mitra Komnas Perempuan sejumlah 13.602 kasus;

c. Unit Pelayanan Dan Rujukan (UPR).

Gambaran ini memberikan dugaan bahwa kasus kekerasan terhadap perempuan berdasarkan formulir yang diterima dari lembaga masih merupakan "puncak gunung es", sebab masih banyak formulir yang tidak dilaporkan. Dan dari kasus telah diterima oleh lembaga mitra melalui formulir, masih banyak juga yang tidak dilaporkan. Sehingga menimbulkan pertanyaan, mengapa kasus-kasus kekerasan terhadap perempuan tersebut tidak diikutsertakan dalam laporan?

Namun dari sisi lain ternyata, keberadaan Organisasi Masyarakat Sipil (OMS) memiliki peran yang besar dalam penanganan kasus kekerasan terhadap perempuan, hal ini menunjukkan bahwa dalam masyarakat terdapat mekanisme penyelesaian sengketa alternatif, yang digunakan oleh masyarakat untuk mendapatkan keadilan dan kepastian hukum. Hal ini menunjukkan bahwa aparatur

\footnotetext{
${ }^{5}$ Catatan Tahun 2017, Laporan Kekerasan Terhadap Perempuan, https://drive.google.com/file/d/0BwSyakH_J8_nRkRNTVBxX0Q1aWs/view ， diakses 14 September 2018
} 
hukum masih menganut paham legal positivism, bahwa bila hukum sudah dibuat, maka berbagai persoalan dalam masyarakat berkenaan dengan apa yang diatur dalam hukum tersebut, sudah dapat diatasi atau bahkan dianggap selesai. Walaupun demikian, kita harus menyadari bahwa hukum yang dibuat oleh negara bukanlah satu-satunya acuan prilaku manusia, sehingga apabila perangkat hukumnya tidak lengkap dan tidak jelas, maka harus dicarikan dan ditemukan ${ }^{6}$ sumber hukum dalam wujud penemuan hukum, agar menciptakan hukum yang kondusif di masyarakat.

Fenomena kekerasan dalam rumah tangga tentu saja dapat merupakan salah satu kategori perbuatan kriminal yang dapat di pidanakan. Namun, pemidanaan kasus kekerasan dalam rumah tangga tidak sepenuhnya menyelesaikan masalah kekerasan dalam rumah tangga, bahkan penyelesaian yuridis kasus kekerasan dalam rumah tangga akan membawa dampak sosial dan psikologis yang tidak terhitung kerugiaannya. Secara sosial misalnya, apakah perempuan mendapat kekerasan dalam rumah tangga itu, setelah diselesaikan secara pidana akan dapat kembali tereintegrasi dalam keluarga, baik keluarga inti (dengan suami, anakanak) maupuan hubungan kekerabatan? Dan secara psikologis, akan menimbulkan perasaan aib pada anggota keluarga yang lainnya.

Kehidupan sosial manusia selalu diwarnai kekerasan. hal ini memberikan gambaran bahwa hubungan sosial manusia sangat kompleks tidak terhitung jumlah dan jenisnya sehingga tidak semua permasalahan dapat diselesaikan dengan suatu peraturan secara tuntas dan jelas ${ }^{7}$. Sehubungan dengan penjelasan di atas, penulis merumuskan permasalahan sebagai berikut: Apakah Pengadilan Keluarga dapat diterapkan sebagai konsep penyelesaian perkara kekerasan terhadap perempuan?

\section{PEMBAHASAN}

\section{Gambaran Kekerasan Terhadap Perempuan.}

Menurut laporan Komnas Perempuan bahwa kekerasan terhadap perempuan sejak tahun 2010 terus meningkat dari tahun ke tahun. Peningkatan angka yang sangat tinggi terjadi antara tahun 2011 sampai tahun 2012 yang mencapai $35 \%$.

\footnotetext{
${ }^{6}$ H. Yudha Bakti, Course Materials "Penemuan Hukum”, Program Pascasarjana Magister Hukum Universitas Padjajaran, Bandung, 2007, hlm.3.

${ }^{7}$ Ibid, hlm. 1.
} 
Untuk tahun 2015 jumlah kasus meningkat sebesar 9\% dari tahun $2014^{8}$. Komnas Perlindungan Anak misalnya melaporkan bahwa perempuan pelaku kekerasan dalam rumah tangga (KDRT) terlebih dahulu merupakan korban kekerasan oleh suaminya dan berada dalam kondisi terjepit oleh tekanan ekonomi akibat proses pemiskinan yang sedang dialami secara umum oleh masyarakat. KOMPAS (4/01/06) memberitakan bahwa seorang ibu rumah tangga (22 tahun) dari Serpong yang terpaksa membakar kedua anaknya karena tidak tahan terhadap suami yang selalu bertindak kasar terhadap dirinya padahal sang suami menganggur dan sering minum minuman beralkohol.

Berdasarkan Laporan Komnas Perempuan 2017, posisi pertama ditempati oleh kekerasan dalam rumah tangga terhadap perempuan sebanyak tercatat 10.205 kasus. Dari jumlah tersebut, kekerasan terhadap istri (KTI) sebesar 57\% (5.784), kekerasan dalam pacaran (KDP) sebesar 21\% (2.171), dan kekerasan terhadap anak perempuan (KTAP) sebesar 18\% (1.799). Selanjutnya sisanya adalah kekerasan mantan suami (KMS), mantan pacar (KMP), pekerja rumah tangga (PRT) dan ranah personal lain. Berkaitan dengan kekerasan dalam rumah tangga terhadap perempuan, bentuk kekerasan yang paling menonjol adalah kekerasan fisik 4.281 kasus (42\%), menempati peringkat pertama disusul kekerasan seksual kasus 3.495 ( 34\%), psikis 1.451 kasus (14\%) dan ekonomi 978 kasus (10\%). Untuk Posisi kedua adalah kekerasan terhadap perempuan dalam ranah komunitas sebesar 22\% (3.092) dan terakhir adalah kekerasan terhadap perempuan dalam ranah negara sebesar 3\% (305).

Tabel 1: Gambaran Kekerasan terhadap Perempuan

\begin{tabular}{|l|l|l|l|l|l|l|l|}
\hline Tahun & 2010 & 2011 & 2012 & 2013 & 2014 & 2015 & 2016 \\
\hline $\begin{array}{l}\text { Jumlah } \\
\text { Kekerasan }\end{array}$ & 105.103 & 119.107 & 216.156 & 279.688 & 293.220 & 321.751 & 259.150 \\
\hline
\end{tabular}

Sumber: Komnas Perempuan, 2017

Data-data yang terungkap dari tahun ke tahun, merupakan fakta yang mebmberikan dampak yang besar dan mendalam terhadap perempuan, antara lain mengurangi tingkat kepercayaan perempuan (minder), menghambat kemampuan perempuan untuk berpartisipasi penuh dalam kegiatan sosial, menggangggu

\footnotetext{
${ }^{8}$ Op.cit.
} 
kesehatan, dan mengurangi otonomi perempuan, baik dalam bidang ekonomi, politik dan budaya?

\section{Definisi Kekerasan Dan Bentuk-Bentuk Kekerasan.}

Dalam Pasal 1 Undang-Undang Penghapusan Kekerasan Dalam Rumah Tangga (KDRT) No.23/2004 mendefenisikan kekerasan dalam rumah tangga sebagai suatu perbuatan terhadap seseorang terutama perempuan, yang berakibat timbulnya kesengsaraan atau penderitaan secara fisik, seksual, psikologis, dan atau penelantaran rumah tangga termasuk ancaman untuk melakukan perbuatan, pemaksaan, atau perampasan kemerdekaan secara melawan hukum dalam ruang lingkup rumah tangga.

Erich Fromm, yang merupakan filsuf dari Jerman, bahkan pernah menekuni ilmu hukum, sosiologi serta psikologi dari Jerman, yang pernah belajar ilmu hukum, sosiologi dan psikologi menegaskan kekerasan yang dilakukan oleh manusia bersumber dari situasi dimana seseorang mengalami hambatan untuk bertumbuh secara baik ${ }^{10}$. Fromm merumuskan dua faktor yang menjadi pemicu tindakan kekerasan dalam diri seseorang, yakni ${ }^{11}$; pertama, Agresi defensif merupakan bentuk kekerasan yang dilakukan untuk mempertahankan sesuatu yang berharga bagi dirinya sendiri yang disebut. Bentuk ini sebagai reaksi atas adanya ancaman terhadap hal-hal yang mendasar dalam dirinya. Yang mana orang tersebut menghayati nilai-nilai dan memiliki pegangan dasar dalam hidupnya, sebagai orang yang bebas dan berhati nurani. Oleh karenanya kekerasan yang dilakukan tidak bertujuan untuk mematikan atau menghancurkan orang lain, tetapi sebagai tindakan untuk mempertahankan kehidupan yang penting sebagai eksistensi manusia. Kedua, Agresi destruktif, merupakan bentuk kekerasan yang terjadi karena kemauan sungguh-sungguh untuk menyengsarakan orang lain. Bentuk ini dilakukan untuk menyengsarakan dan menyiksa secara kejam, dan nafsu membunuh dan menghancurkan demi kesenangan. Tindakan ini bukan

\footnotetext{
${ }^{9}$ Ruby Hadiarti Johny, Tindak Pidana Kekerasan Terhadap Perempuan (Studi Etiologi Kriminal di Wilayah Hukum Polres Banyumas), Jurnal Dinamika Hukum, Vol.11 Nomor 2 Mei, 2011, hlm. 215

${ }^{10}$ Erich Fromm dalam Kasdin Sihotang, Kekersaan: Wujud Kehampaan Eksistensi Sebuah Tinjauan Etis atas Pemikiran Erich Fromm, Respons, Jurnal Etika Sosial, Pusat Pengembangan Etika Universitas Atma jaya, Jakarta: Vol. 14 Nomor 02, Desember, 2009. Hlm. 185. Bandingkan juga dengan Maria Silvya E. Wangga, Prinsip Hukum Perlindungan Terhadap Anak Korban Kekerasan, Jurnal Ilmu Hukum Universitas Islam Syekh Yusuf, Tangerang, 2011

${ }^{11}$ Ibid. hlm 186-187
} 
untuk memelihara kelangsungan hidup secara mendasar tetapi hanya demi pemenuhan nikmat untuk menyiksa dan membunuh itu sendiri. Bentuk kekerasan ini merupakan tanggapan atas kondisi panik akan eksistensi manusia yang terisolasi, yang tak berdaya dan merasa kehilangan jati diri manusia ${ }^{12}$.

Bentuk-bentuk kekerasan terhadap perempuan, yang dirumuskan dalam Undang-Undang Penghapusan Kekerasan Dalam Rumah Tangga (UU PKDRT), antara lain: ${ }^{13}$

a. Kekerasan fisik, dalam Pasal 6 diuraikan sebagai, perbuatan yang mengakibatkan rasa sakit, jatuh sakit, atau luka berat dan membunuh. termasuk; diberi racun, diberi obat yang salah, ditenggelamkan, dijambak, ditendang, diinjak, dicubit, dicekik, dicakar, ditempel besi panas, dipukul dengan karet timba, dll.

b. Kekerasan seksual dan eksploitasi seksual, ditegaskan dalam Pasal 8, mendefenisikan kekerasan seksual sebagai setiap perbuatan pemaksaan hubungan seksual, dan meliputi; diperkosa, disodomi, diraba-raba alat kelaminnya dan pahanya, diremas-remas payudaranya, dicolek pantatnya, dipaksa melakukan seks oral dan seks anal, mengekspos perempuan untuk keperluan pornografi (video), dijual pada mucikari, dipaksa menjadi pelacur dan dipaksa bekerja pada warung remang-remang.

c. Kekerasan Psikis, diatur dalam Pasal 7 bahwa, perbuatan yang mengakibatkan ketakutan, hilangnya rasa percaya diri, hilangnya kemampuan untuk bertindak, rasa tidak berdaya, dan/atau penderitaan psikis pada seseorang.misalnya; dihina, dicaci maki, dipaksa melakukan sesuatu yang tidak dikehendaki dan diancam, dibentak karena dianggap bodoh, Kekerasan eksploitasi fisik untuk kepentingan ekonomi. Jenis kekerasan psikis ini ada yang menyebutnya dengan kekerasan simbolik ${ }^{14}$. Kekerasan simbolik dapat berupa makian, dipelototi, dibentak, diancam, dituduh atau berbagai kekerasan yang mengakibatkan gangguan secara psikis.

12 ibid

${ }^{13}$ Fentiny Nugroho, M. A, Upaya Preventif Dan Kuratif Dengan Pendekatan Keluarga Dan Komunitas Dalam Penanggulangan Dan Penelantaran Anak, Mitra Perempuan dll, Jakarta, Juli, 2001. hlm. 3.

${ }^{14}$ Darmoyo Syarief \& Riato Adi, Trafficking Anak Untuk Pekerja Rumah Tangga, Jakarta: PKPM UAH, 2004,hlm.65 
d. Kekerasan yang diakibatkan oleh tradisi/adat, antara lain; dipaksa kawin pada usia muda bagi perempuan (pemaksaan perjodohan untuk meningkatkan status keluarga), masih terjadi di beberapa daerah di Indonesia. (sebagai contoh lain adalah tradisi pemotongan ruas jari di Papua pada saat orang tua meninggal dunia, serta jual beli anak karena himpitan ekonomi dan hutang).

e. kekerasan ekonomi, dinyatakan dalam Pasal 9 ayat (1), berupa penelantaran rumah tangga yang padahal menurut hukum yang berlaku ia wajib memberikan kehidupan, perawatan, atau pemeliharaan kepada orang tersebut.

\section{Kekerasan Terhadap Perempuan}

Suatu perbuatan yang dilakukan dengan kekerasan, ancaman kekerasan, yang mengakibatkan luka atau kematian, menuntut sipelaku bertanggung jawab atas perbuatan tersebut, yang dalam rumusan pidana, sebagai perbuatan pidana. Akibat hukum yang diberikan kepada pelaku perbuatan pidana, dapat kita dijumpai dalam KUHP dan Undang-Undang Nomor. 23 Tahun 2004 tentang Penghapusan Kekerasan Dalam Rumah Tangga khususnya Pasal 44 sampai dengan Pasal 49 dan juga pidana tambahan dalam Pasal 50. Penganut paham legal positivism, memiliki pandangan bahwap pendekatan yuridis pada dasarnya dilakukan untuk memberikan efek jera agar sipelaku menyadari perbuatannya sehingga diharapkan di waktu yang akan datang tidak mengulangi lagi perbuatannya. Tetapi lebih dari itu merupakan suatu jaminan keadilan kepada setiap individu.

Berdasarkan uraian diatas maka pendekatan yuridis tidak cukup bahkan juga tidak kompeten untuk mengungkap fenomena kekerasan secara radikal, sampai ke akar-akar persoalannya. Mengungkap akar-akar persoalan kekerasan terhadap perempuan menyangkut nilai yang lebih progesif dalam arti pengungkapan itu akan mendorong penilaian yuridis yang lebih komprehensif untuk mengatasi kekerasan pada perempuan. Berdasarkan pemaparan di atas, maka akar 
permasalahan kekerasan terhadap perempuan, yang terus menerus meningkat setiap tahun disebabkan oleh beberapa faktor:

a. faktor dari budaya masyarakat :

1) budaya patrirkhi yang menempatkan posisi laki-laki sebagai penentu kebijakan,

2) Kurangnya pemahaman dan pengertian dalam berkomunikasi;

3) Ekonomi keluarga rendah/kesenjangan pendapatan antara suami dan isteri;

4) Adanya tindakan semena-mena, baik dari suami, keluarga maupun oleh aparatur hukum;

5) Pengalaman hidup yang dibesarkan dengan kekerasan, dll

b. faktor dari perangkat hukum:

1) Penegakkan hukum yang lemah, yang hanya mengacu pada hukum positif;

2) Perangkat hukum yang tidak profesional dengan menempatkan diri sebagai penguasa, bukan pelayan;

3) Pelaksana pengadilan perkara perempuan tidak memiliki minat, bakat dan kepekaan terhadap persoalannya;

4) Ruang pengadilan yang mencerminkan struktur dominasi kekuasaan;

5) Tata cara pelaksanaan pengadilan seperti ruang dan waktu yang memberikan privacy yang cukup bagi keluarga;

6) Keputusan pengadilan yang tidak menyelesaiakan persoalan ${ }^{15}$.

Berdasarkan uraian yang ada, maka penulis mempertanyakan dapatkah hukum positif menyelesaikan masalah kekerasan yang saat ini? Apakah perlu pendekatan yuridis - sosiologis.

\section{Pengakuan Hukum Positif Perlindungan Hak Perempuan.}

Pengakuan yuridis terhadap apa yang dikemukakan secara filosofis di atas dapat kita temukan dalam Deklarasi Universal mengenai Hak-Hak Asasi Manusia, Undang-undang Dasar 1945, Undang-Undang Nomor 39 Tahun 1999 tentang Hak

\footnotetext{
${ }^{15}$ Sulistyowati Irianto dan Antonius Cahyadi, Runtuhnya Sekat Perdata Dan Pidana, Studi Peradilan Kasus Kekerasan Terhadap Perempuan, Pusat Kajian Wanita Dan Jender Universitas Indonesia dan Yyasan Obor Indonesia, 2008, hlm. 319.
} 
Asasi Manusia, Undang-Undang Perkawinan Nomor 1 Tahun 1974 dan UndangUndang No. 23 Tahun 2004 tentang Penghapusan Kekerasan Dalam Rumah Tangga. Ketentuan-ketentuan yuridis tersebut akan diuraikan secara singkat berikut ini.

\subsection{Deklarasi Universal Hak Asasi Manusia}

Ada beberapa prinsip dalam Deklarasi Universal HAM memberikan pengakuan dan perlindungan terhadap hak-hak setiap individu yang paling mendasar yakni: dalam Pasal 1 mengakui bahwa semua manusia dilahirkan merdeka dan setara dalam martabat serta hak-hak. Mereka dikaruniai dengan akal budi dan suara hati, dan hendaknya bergaul satu sama lain dalam semangat persaudaraan semua manusia dilahirkan merdeka dan setara dalam martabat serta hak-hak. Pasal 3 menegaskan bahwa setiap orang memiliki hak untuk hidup, kebebasan dan keamanan pribadi setiap orang memiliki hak untuk hidup, kebebasan dan keamanan pribadi) Dalam Pasal 5 lebih jelas lagi ditegaskan penolakan terhadap kekerasan dengan menegaskan bahwa tidak seorangpun boleh disiksa atau dianiaya, diperlakukan atau dihukum secara tidak berperikemanusiaan atau dengan merendahkan derajat. setiap orang memiliki hak untuk hidup, kebebasan dan keamanan pribadi. penolakan terhadap kekerasan dengan menegaskan bahwa tidak seorangpun boleh disiksa atau dianiaya, diperlakukan atau dihukum secara tidak berperikemanusiaan atau dengan merendahkan derajat.

2.2. Perubahan Kedua Undang-Undang Dasar Negara Republik Indonesia 1945

Pasal $28 \mathrm{G}$ ayat (1) mengatakan bahwa, setiap orang berhak atas perlindungan diri peribadi, keluarga, kehormatan, martabat dan harta benda yang dibawah kekuasaannya, serta berhak atas rasa aman dan perlindungan dari ancaman ketakutan untuk berbuat atau tidak berbuat sesuatu yang merupakan hak asasi. . Sedangkan dalam pasal $28 \mathrm{H}$ ayat 2 menegaskan bahwa setiap orang berhak mendapat kemudahan dan perlakuan khusus untuk memperoleh kesempatan dan manfaat yang sama guna mencapai perasamaan dan keadilan. Rumusan-rumusan ini memberi penegasan bahwa manusia adalah mahluk yang memiliki hak asasi yang mendasar yang wajib dihormati oleh sesamanya.

2.3. Undang-Undang No. 39 Tahun 1999 tentang Hak Asasi Manusia. 
Dalam Pasal 3 ayat (1) menjelaskan bahwa setiap orang dilahirkan bebas, dengan harkat dan martabat yang sama dan sederajat serta dikaruniai akal dan hati nurani untuk hidup bermasyarakat, berbangsa dan bernegara dalam semangat persaudaraan. Pasal ini hampir sama bunyinya dengan pasal 1 Deklarasi Univerasal Hak-Hak Asasi Manusia. Adapun pasal 3 menyatakan bahwa setiap orang berhak atas perlindungan hak asasi manusia dan kebebasan dasar tanpa didiskriminasi.Sedangkan Pasal 4 mengatur bahwa, hak untuk hidup, hak untuk tidak disiksa, hak kebebasan pribadi, pikiran dan hati nurani, hak beragama, hak untuk tidak diperbudak, hak untuk diakui secara pribadi dan persamaan dihadapan hukum dan hak untuk tidak dituntut atas dasar hukum yang berlaku surut adalah hak asasi manusia yang tidak dapat dikurangi dalam keadaan apapun dan oleh siapapun.

Pada Pasal 9 ditegaskan mengenai peningkatan taraf hidup. Dalam ayat (1) diakui bahwa setiap orang berhak untuk hidup, mempertahankan hidup dan meningkatkan taraf kehidupannya. Sedangkan ayat (2) memberikan perlindungan terhadap hak untuk merasa tenteram, aman, damai, bahagia, sejahtera lahir dan batin. Ketentuan khusus mengenai hak dan kewajiban isteri dan suami dalam rumah tangga dapat kita temukan dalam Pasal 51 Ayat (1) dari pasal ini menegaskan bahwa seorang isteri selama dalam ikatan perkawinan mempunyai hak dan tanggungjawab yang sama dengan suaminya atas semua hal yang berkenaan dengan kehidupan perkawinannya, hubungan dengan anak-anak dan hak pemilikan serta pengelolaan harta bersama.

Selain itu dalam Pasal 69 menggarisbawahi kewajiban setiap orang terhadap setiap orang lainnya, termasuk dalam hal ini kewajiban pemerintah. Ayat (1) berbunyi, setiap orang wajib menghormati hak asasi manusia orang lain, moral, etika dan tata tertip kehidupan bermasyarakat, berbangsa dan bernegara. Sedangkan ayat 2 berbunyi, setiap hak asasi manusia seseorang menimbulkan kewajiban dasar dan tanggungjawab untuk menghormati hak asasi orang lain secara timbal balik serta menjadi tugas pemerintah untuk menghormati, melindungi, menegakkan dan memajukannya.

2.4. Undang-Undang Nomor 1 Tahun 1974 tentang Perkawinan. 
Perhatian pemerintah untuk mewujudkan keutuhan dan kerukunan dalam kehidupan berumah tangga ditegaskan dalam beberapa pasal seperti Pasal 1 menyatakan, bahwa perkawinan sebagai ikatan lahir batin antara seorang dan seorang wanita sebagai suami/isteri dengan tujuan membentuk keluarga (rumah tangga) yang bahagia dan kekal berdasarkan keTuhanan Yang Maha Esa. Sedangkan Pasal 31 ayat (1) menyatakan, bahwa hak dan kedudukan suami dalam kehidupan rumah tangga dan pergaulan hidup bersama dalam masyarakat. Selanjutnya Pasal 33 menyatakan, bahwa suami/isteri wajib saling mencintai, hormat menghormati, setia dan memberi bantuan lahir dan batin yang satu kepada yang lain, dan Pasal 34 menyatakan, suami/isteri wajib saling melindungi isterinya dan memberikan segala sesuatu keperluan hidup berumah tangga sesuai dengan kemampuannya.

2.5.Undang-Undang Nomor 23 Tahun 2004 tentang Penghapusan Kekerasan Dalam Rumah Tangga.

Keberadaan peraturan ini diharapkan memberi perubahan yang signifikan dalam mengakhiri atau meminimalisasi setiap kekerasan dalam rumah tangga. Dalam pembukaan Undang-undang ini dinyatakan secara tegas, bahwa setiap warga negara berhak mendapatkan rasa aman dan bebas dari segala bentuk kekerasan sesuai dengan falsafah negara kita, apabila terjadi segala bentuk kekerasan, terutama kekerasan dalam rumah tangga, hal ini merupakan pelanggaran hak asasi manusia dan kejahatan terhadap martabat kemanusiaan. Penghapusan kekerasan dalam rumah tangga didasarkan pada asas penghormatan hak asasi manusia, keadilan dan kesetaraan gender, non diskriminasi dan perlindungan korban. Dengan demikian kepada para pelaku kekerasan dikenakan ancaman hukuman pemidanaan penjara dan denda, yang diatur dalam Pasal 44 sampai Pasal 49, sedangkan Pasal 50 berupa pidana tambahan. Pidana merupakan derita yang diberikan secara sadar dan sengaja kepada seseorang atausekelompok orang yang melakukan kejahatan, untuk memberikan efek jera agar si pelaku menyadari perbuatannya.

\section{Alternatif Penyelesaian Kekerasan Terhadap Perempuan.}

Penegakkan hukum dengan memberikan kepastian hukum (Rechtssicherheit), kemanfaatan (zweckmassigkeit) dan keadilan (gerechtigkeit) 
bagi perempuan kepastian hukum, sudah harus dilakukan yaitu dengan melakukan kajian sosio-legal studies, yang bersifat interdisipliner, dengan pendekatan hukum, sosiologi dan studi budaya, sehingga perangkat hukum yang dapat dipakai adalah yang berasal dan hidup dari masyarakat, sehingga ketika hukum itu diterapkan kembali dalam masyarakat tidak terjadi benturan dengan keadaan sosial budaya yang ada. Hal terlihat dalam mekanisme pengadilan perkara kekerasan terhadap perempuan, dimana tidak semua mengacu pada hukum positif yang sudah ada, khususnya Undang-Undang No. 23 Tahun 2004 tentang Penghapusan Kekerasan Dalam Rumah Tangga ${ }^{16}$. Seperti apakah bentuk hukum yang dapat memenuhi konteks sosial dan budaya masyarakat lokal, mungkin kita perlu melihat dan mempelajari misalnya dengan Ethnography of law, yang dikembangkan untuk mengkaji forum penyelesaian sengketa berbasis komunitas biasa yang dijumpai dalam kehidupan keseharian. Atau Samia Bano menggunakan etnografi untuk meneliti penggunaan lembaga hukum yang tidak resmi (unofficial legal bodies), seperti Shariah Councils, dikalangan perempuan muslim Asia Selatan yang tinggal di Inggris atau Anne Griffiths, menggunakan peneliti lapangan"berhukum" masyarakat tersebut dalam kehidupan keseharian dan dalam memberi respon kepada gagasan hukum barat ${ }^{17}$.

Bertitik tolak pada pandangan bahwa masalah kehidupan manusia yang begitu kongkrit, luas dan kompleks dalam masyarakat, tidak hanya harus dipecahkan dengan undang-undang, karena Undang-Undang bukan satu-satunya sumber hukum, akan tetapi masih ada sumber-sumber lainnya yang dapat digunakan dalam penyelesaian dan penegakkan hukum di masyarakat ${ }^{18}$. Sumber hukum inilah yang ditawarkan oleh ilmuwan, karena harus bertindak sebagai agen sosial. Sebagaimana di beberapa negara telah memiliki pengadilan keluarga, (family Court), antara lain: Canada, Amerika, New Zealand, Australia, Inggris dan Jepang, dan di Asia Selatan antara lain: Filipina, Malaysia, dan Singapura. Untuk di Amerika, Australia dan Singapura, yang telah memiliki pengadilan keluarga,

\footnotetext{
${ }^{16}$ Sulistyowati Irianto dan Antonius Cahyadi, Ibid. hlm.6.

${ }^{17}$ Ibid. hlm. 10.

${ }^{18}$ H.Yudha Bakti, Aliran-Aliran Penemuan Hukum, Dalam Course Materials Penemuan Hukum, Program Pascasarjana Magister Hukum Universitas Padjajaran Bandung, 2008, hlm. 34.
} 
dengan menyediakan forum penyelesaian sengketa dengan cara mediasi, bagi seluruh konflik yang berhubungan dengan keluarga.

Pada hakekatnya, prinsip yang perlu diperhatikan dalam pengadilan keluarga, seperti yang dianut dalam principal family court Of New Zealand, antara lain:

a. hakim yang khusus;

b. privacy untuk keluarga dalam court hearing;

c. pengadilan Dalam bedikenal dengan pengadilan keluarga;

d. hukum pembuktian yang lebih memperhatikan hak perempuan;

e. layanan konseling gratis untuk mengadakan rekonsiliasi;

f. bila memungkinkan penyelesaian keluarga melalui konsiliasi;

g. pengadilan harus dilengkapi dengan ahli psikologi, dll.

Wacana pengadilan keluarga yang menyelesaikan perkara kekerasan terhadap perempuan di indonesia, tentunya harus melalui kajian yang lebih komprehensif dengan melakukan studi interdisipliner, karena keadaan sosial dan budaya setiap bangsa sangat berbeda, namun bila kita mau belajar dari sejarah bangsa kita, para ahli hukum adat dan tokoh masyarakat sebenarnya sudah memiliki cara penyelesaian dari budaya masyarakat, seperti yang nampak dalam, Logika Sanggraha, sebagai salah satu jenis penyelesaian masyarakat adat di Bali.

\section{PENUTUP}

Kekerasan sepertinya tidak akan pernah hilang dari muka bumi ini, sebagaimana pula tindakan kejahatan lainnya, akan tetapi bukan berarti frekuensi dan jumlah tindakan kekerasan terhadap perempuan tidak dapat diminimalisir. Untuk mencapai hal ini, apakah pendekatan yuridis yang ada saat ini sudah cukup? Pendekatan yuridis pada dasarnya berhubungan dengan subyek hukum sedangkan budaya bukan merupakan subyek hukum. Budaya menyangkut nilainilai, norma dan kepercayaan-kepercayaan dalam masyarakat dan oleh karena itu tidak rasional untuk didekati secara yuridis. Sesuatu yang bersifat kultural harus juga didekati secara kultural yakni dengan menginternalisasikan nilai-nilai baru yang dapat menghasilkan perangkat hukum yang progresif, dengan memiliki paradigma baru lembaga-lembaga hukum berfungsi sebagai agen legal-sosial 
yang mensosialisasikan nilai-nilai, dengan menerapkan konsep baru penyelasaian kekerasan terhadap perempuan, berupa pengadilan keluarga, konsep yang berasal dari masyarakat lokal.

\section{DAFTAR PUSTAKA}

\section{Buku}

Darmoyo Syarief \& Riato Adi, Trafficking Anak Untuk Pekerja Rumah Tangga, Jakarta: PKPM UAH, 2004.

Fentiny Nugroho, M. A, Upaya Preventif Dan Kuratif Dengan Pendekatan Keluarga Dan Komunitas Dalam Penanggulangan Dan Penelantaran Anak, Mitra Perempuan dll, Jakarta, Juli, 2001.

H.Yudha Bakti, Aliran-Aliran Penemuan Hukum, Dalam Course Materials Penemuan Hukum, Program Pascasarjana Magister Hukum Universitas Padjajaran Bandung, 2008.

H.Yudha Bakti, Course Materials "Penemuan Hukum, Program Pascasarjana Magister Hukum Universitas Padjajaran, Bandung, 2007.

Kuper Adam dan Jessica Kuper. Ensiklopedi Ilmu-Ilmu Sosial. (diterjemahkan oleh Harismunandar, et.all.), Jakarta: PT. Raja Grafindo Persada, 2000.

Sulistyowati Irianto dan Antonius Cahyadi, Runtuhnya Sekat Perdata Dan Pidana, Studi Peradilan Kasus Kekerasan Terhadap Perempuan", Pusat Kajian Wanita Dan Jender Universitas Indonesia dan Yyasan Obor Indonesia, 2008.

\section{Jurnal}


Kasdin Sihotang, Kekersaan: Wujud Kehampaan Eksistensi Sebuah Tinjauan Etis atas Pemikiran Erich Fromm, Respons, Jurnal Etika Sosial, Pusat Pengembangan Etika Universitas Atma jaya, Jakarta: Vol. 14 Nomor 02, Desember, 2009.

Maria Silvya E. Wangga, Kekerasan Dalam Rumah Tangga dan Usaha Merumuskan Relasi Familial Yang Demokratis, Jurnal Ilmu Hukum Universitas Islam Syekh Yusuf, Tangerang, 2007.

Maria Silvya E. Wangga, Prinsip Hukum Perlindungan Terhadap Anak Korban Kekerasan, Jurnal Ilmu Hukum Universitas Islam Syekh Yusuf, Tangerang, 2011.

Ruby Hadiarti Johny, Tindak Pidana Kekerasan Terhadap Perempuan (Studi Etiologi Kriminal di Wilayah Hukum Polres Banyumas), Jurnal Dinamika Hukum, Vol.11 Nomor 2 Mei, 2011

\section{Peraturan Perundang-undangan}

Deklarasi Universal HAM.

Perubahan Kedua Undang-Undang Dasar Negara Republik Indonesia 1945

Indonesia. Undang-undang Nomor 1 Tahun 1974 tentang Perkawinan. LN No.1 Tahun 1974 TLN No. 3019

Indonesia. Undang-undang Nomor 39 Tahun 1999 tentang HAM. LN No. 165 Tahun 1999 TLN No. 3886.

Indonesia. Undang-undang Nomor 23 Tahun2004 tentang Penghapusan Kekerasan Dalam Rumah Tangga. LN No. 95 Tahun 2004 TLN No. 4419. 